\title{
近代化のアンビバレンスの視点から見た 教育制度・学校・青年期の関係の変容
}

\author{
ヴェルナー・ヘルスパー (ハレ大学) \\ メーレ・フムリヒ (ハレ大学) \\ 訳：ビアルケ（當山）千咲 (国際基督教大学)
}

近年のドイツの教育制度に生じた変化は, 社会変容という包括的な過程を視野に 入れて理解しなければならない。この変容は, グローバル, ヨーロッパ, ドイツと いう視点からそれぞれ考察することができる。ドイツ国内に関しては, 第 1 に全体 的な変化, 第 2 に連邦と州の関係 (州の教育決定権をめぐる両者間の関係), 第 3 に 1990年以降のドイツ統一の変容過程の 3 つに区別できる。

本稿では，まず第 1 に主要な社会変容の流れを押さえた上で，それが教育制度の 変化にどのような意味を持っているかを明確化する。第 2 に子ども・青年の成長の 条件の変化について, 彼らの学校へのかかわり方を例として述べる。最後に重要な 研究動向を概観し, 社会変容の過程と成長の条件の関係をテーゼの形でまとめるこ とにする。

\section{1 . 近代化のアンビバレンスの視点から見た教育制度の変容}

社会の変容過程を近代化の過程と理解するならば，個々の社会をその近代化のレ ベルという軸に沿って評価するという危険性が常に存在する。そのような場合ード イツ統一の分析においてもそうなのだがー「部分的」「後進的」あるいは「選択的」 な近代化（Helsper u. a. 2001）といった，多かれ少なかれ久損構造を指摘するよう な形になってしまう。こうした性急な価値づけを避けるために, 本稿では変容過程 をアンビバレンスとアンチノミーという視点から考察する (Giddens 1995)。

\section{1. 近代化のアンチノミー}

近代化のアンビバレンスないしアンチノミーとは何か？ 近代化の過程は直線的 
でなく, 常に相反する過程を引き起こす。したがって個人化の過程はそれ自体アン ビバレントなだけでなく，新しい依存関係と強制を伴うものである。近代化はより 良い状態への直線的な発展の流れとしてでなく, それ自体緊張に満ちた相反する事 態を引き起こす過程と理解できる。ここでは近代化のアンチノミーを次の 4 つに区 別する (Helsper u. a. 2001)。

・個人化のアンチノミー

・合理化のアンチノミー

・多元化・多様化のアンチノミー

・文明化のアンチノミー

個人化のアンビバレンスとは, 伝統的な生活形態や生活様式からの個人の解放に おける緊張関係である。これにより個人の選択の自由が広がり，個人のアイデンテ イティはより開放的でうつろいやすく拡散した可変なものになる。個人は多様なイ デオロギーの部分的システムの世界において，どこにも全体的に属することなく， 「複数の世界間の放浪者」となる。個人は自己コラージュを作り上げるように多様な ものを関連づけ，「パッチワーク・アイデンティティ」や「自分で組み立てる自伝 (Biographie)」が生まれる。しかしそれは，個人が自身の人生をつくりあげること に関して，より大きな責任を負うようになり，「自由への強制」に直面するようにな ったということでもある。様々な将来を再帰的に設計し，多様な選択肢を視野に入 れながら人生を作り上げるということは新しい重荷を伴う。さらにこの新しい自由 と同時に, 人は生活世界から切り離され社会的な絆は緩まるのである。これによっ て地域の共同体による直接の社会的統制や他者による統制は弱まり, 新しい発達の 可能性が生まれる。しかしギデンズ（1995，p. 33）が「脱埋め込み」と呼ぶ事態も 生じ，それは自由の可能性と同時に「自由の重荷」ももたらしうる。そこに生まれ る新しい依存状態とは，身近な他者による直接の規範的な統制によるものではない。 その統制と依存状態は，むしろ抽象的なシステムと組織の強制に移行してきている のであり，個人は一一新しい自由を得ながらも—そうした強制下に置かれている。

ここに合理化のアンチノミーが生じることになる。第 1 に, 個人の影響が及ばな い抽象的なシステムの命令と操作媒体が，人々の生活文脈の形成に幅広く介入し， 合理化の圧力をかけるようになっている。例えば取引所の相場や為替の変動などが 生活環境や地域社会を根本から変容させうるのである。第 2 に, 近隣の小規模な地 域社会の統制の代わりに，一そのような統制メカニズムも完全には失われないで あろうが一一社会的な組織への依存が取って替わるようになる。それは普遍主義的 
近代化のアンビバレンスの視点から見た教育制度 · 学校・青年期の関係の变容

な参加・権利・安全等を保障するためのものであるが，同時に個人の特殊性を度外 視する規格や法律も導入する。近年，個人が組織やその規定に依存するようになる 一方で, 組織は個人に対し自律と自己責任を強調するようにもなっている。こうし て個人を尊重しょうとする組織が，同時に自己責任をますます主張するという矛盾 した状況が生じている。抽象的な強制と依存状態は，自己責任と自立への強制とい う形態をとるようになるのである。

以上のような普遍化の現象は，これに相反する多様化や小規模レベル・地域レベ ルの多様化の過程を伴うものでもある。この緊張関係は多様化のアンビバレンスと 呼ぶことができる。このアンビバレンスが最も顕著に現れているのは，文化的な領 域に全般的に生じているグローバル化である。例えば衣食住なども含む日常生活文 化においてはグローバルなブランドやスタイル等が世界規模で広がり，今日世界中 どこでもアクセス可能になっている。そのため国家・地方・地域レベルの伝統や意 味体系は普遍化の圧力下に置かれてしまう。つまりそれらはグローバルに共有され ている普遍化された意味体系やライフスタイルに刺激され，侵食されてしまう。同 時に様々な地域的・文化的なコンテクストにおいて，別の世界の解釈にアクセスす ることも可能になっている。これによって視野が広がり, 文化的解釈の蓄積の中心 は不明瞭になり, 多元化・多様化が生じる。地域・地方レベルの解釈の蓄積から新 しい生活様式や文化が生み出されたり組み立てられうる。これは, 多様性を可能に するポストモダンにおいて新しい複雑性が生まれる過程であると同時に，大きな物 語の終焉を伴う過程でもある。このように，文化的な解釈の蓄積や意味体系，世界 と自己の解釈のみならず，生活状況や生活スタイルまでもが普遍化されながら，同 時にラディカルな多元化・多様化も生じるという事態こそが，「再帰的な近代」に特 徵的な現象といえよう。過去20-30年の移民現象も，この文化の普遍化と多椂化の 相互作用にエスニシティと文化の差異の経験を付け加えていることはいうまでもな い。

これらの近代化の方向の中で，解放された個人は自己との関係を新しく築くよう になる。自己反省・自己省察をし, 自己観察を学び, 複雑で高度に近代化された社 会の中で行くべき方向を見失わないように，また自分の人生を自己責任によって作 り上げるために久かせない態度を身につける。合理化の過程がもたらすシステムの 強制や行為と時間の経済性ゆえに，個人は自身をより厳しく統制しなければならな い。個人は合理化された社会を生き抜くために，ある意味で自己内合理化を図らな ければならなくなる。個人は自己反省をし，自身の行動を観察・統制しなければな 
らないことにより，主観的な世界を発見し，それを社会的に構成するに至る。すな わちそこに激しい感情, 悩み, 欲求の主観的な宇宙が生まれる。これは美的経験領 域において洗練され，美的な形態をとり，主観的な幸福，愛，親密さ，経験性に関 する新しいレベルの要求として放出される。自己統制への要請が高まる一方で，同 時に唯一無二の存在として感情的に認められ愛されることや，陶然たる感覚的経験 への欲求が拡大する事態を，文明化のアンチノミーと呼ぶことができる。

以上のような近代化のアンビバレンスとの関連において，ドイツの教育制度の主 要な変化はどのように位置づけられるであろうか。以下では最も重要な変化を描く ことにする。

\section{2. 個人化のアンチノミーの視点からみたドイッの教育制度}

ドイツの学校制度は，他のヨーロッパの制度（例えばフィンランドやスウェーデ ン）と異なり, 明確に分岐型となっており（基幹学校, 実科学校, ギムナジウムの 3 分岐型, 州によっては総合制学校が加わった 4 分岐型), 生徒は10歳という早い時 期に異なる学校種に分けられる。教育の不平等に関する実証的研究では, 早期に生 徒を異なる学力レベルに分けることが，ドイツの教育における不平等の生成をかな り助長していることを証明している。PISA が示したように, 不平等は再生産され続 けている (Baumert u. a. 2001, Prenzel u. a. 2004)。このような結果はドイツの学 校制度が再生産の装置となっていることの現われとも読める。しかしこれはあくま で見そう見えるにすぎない。なぜならこの再生産の構造内で大規模な個人化への変 容が生じているからである。

- 教育機会の不平等が根強く残るにもかかわらず, より高いレベルの学歴取得者 が増加している。アビトゥア (大学入学資格) 取得者は, 旧西ドイツでは 1 学 年の 3 分の 1 にも達し，1950年代の 5 倍近くになった。旧東ドイツでは統一後 3 年以内で 80 年代末の $11 \%$ から $30 \%$ 以上に上昇した (Helsper/Hummrich 2005)。高等教育が拡大する中，10年生修了時に取得する中等修了証(実科学校 修了証）が標準的な学歷となった。低学歴層や移民の青少年にも学校教育を継 続して受ける新しい道が開かれるようにもなった。

- さらに 50 年代から教育アスピレーションが非常に高まり, 子どもに望む学歷と して最もレベルの低い基幹学校修了証を挙げる親は減る一方である。逆にアビ トゥア取得を希望する親は増加している。かつては教育には距離を置いていた 層においても教育アスピレーションが明らかに高まっている。 
近代化のアンビバレンスの視点から見た教育制度 ·学校・青年期の関係の变容

一 最後に, 取得学歴と学校種の関係が弱まり, 様々な学校種においてより高い修 了証を取得する多様なルートが増えていることが挙げられる。色々な学校修了 証を職業学校において取得したり, ある学校種の修了証を別の学校種において 取得することができるようになっている。学歴取得の道が開放的になり, 多様 化しているといえる。さらに州レベルでも地域によって多様化しているため,

ドイツの学校制度は非常に複雑化・多様化している。

このような変化はすべて学歴の自伝化・個人化と捉えることができる。ただし各 学校種への早期の振り分けが再生産されているため, 限定的な個人化といえる。こ の意味で，これまで述べたような個人化のアンビバレンスは教育セクターにも起き ている。教育キャリアの多様化・自伝化はより高い教育を受けるオプションが個人 にとって拡大することである。それによって主観的な変容, 出身階層からの離脱, また生活様式やライフスタイルを変えることが可能になる。しかしこうしたオプシ ヨンの拡大は, 新しい「教育の強制」ともいえる。新しいスタンダードである中等 修了証を取得していない者は，教育制度において「実質的に排除」されてしまう (Bourdieu u. a. 1997)。またその場合, 教育オプションが拡大しているからこそ個 人の失敗と解釈され, 色々なライフチャンスから排除されるのも自己責任であるこ とになってしまう。教育の自由と, 教育の強制, 重荷, 排除される危険性とは交錯 しあっている。この事態は教育のパラドックス, すなわち教育において努力, 計画, 自己統制，投資ということが一層要求されながら，同時に努力が将来のライフチャ ンスに結びつく保証はないという事態を招いているのである。

\section{3. 近代化のアンビバレンスの視点からみたドイツの教育制度の方の他の傾向}

以下ではドイツの教育制度におけるその他の展開について簡単に触れておく。中 心的な学校開発の流れは, 組織としての学校をどのようなものにするかを問題にし ている。いわゆる「教育の市場」が生まれた他の国（オランダ, スウェーデン, 英 国など）と異なり，ドイツでは近年まで学校制度の組織に関する規定が国家によっ て強く統制されていた。その統制は現在も残るものの, 近年例えば学校プログラム の開発や各学校の裁量権の拡大などの形で, 学校の自律性を強めようとする努力が なされてきた。これにより教師や学校関係者自身の持つ教育行為の理論や裁量の範 囲が, 個々の現場の具体的環境や条件にそった形で強められ拡大される一方, 抽象 的でフォーマルな組織的構造に関する規定は一一近年の組織論の研究が示すように， 実際には組織は具体的な行為は決して規定しえなかったのだが——緩められ柔軟に 
なっている。それはしかし学校制度において抽象的な統制的命令がもはや機能しな いという意味ではない。むしろドイツの学校制度における重要な変容とは, インプ ットと前提条件を強く統制する状態から, ナショナル・アセスメントやスタンダー ドを用いたアウトプットによる統制状態へと移行している点にある。かくしてフォ ーマルで官僚主義的な行政上の規制は緩められたが，同時に新しい合理化のダイナ ミズムとアンビバレンスが指摘できる。かつてよりも学校, 教師, 生徒にとつて規 範となり, 従わざるをえないようなスタンダードが生まれ, 包括的に統制されるよ うになっている。しかし，この「世界カリキュラム」的なグローバルなスタンダー ドが合理化の新しい基準を設定しており，各生徒や現場の教師はその達成に関して より大きな責任を負い, 自己責任で学校づくりをするように仕向けられているとい うことでもある。

ドイツの学校制度は, 生徒間の格差が拡大しているという意味で均質ではなくな ってきているが，すべての子どもが振り分けられることなく通う4 年生までの基礎 学校 (小学校) は特にその傾向にある。しかし基礎学校の場合, 生徒の居住地区の 階層的状況によって生徒集団の均質度には大きな差がある。ドイツの学校制度は, 5 年生という生徒の早期振り分けによって学校ないしクラス集団を均質化している。 しかし均質化されたはずのクラス内でも，生徒間には大きな格差がある。特に総合 制学校と基幹学校にはさまざまなエスニシティの生徒や, より高いレベルの学校か ら「落ちこぼされてきた」生徒が集まっている。基幹学校は, 低階層で文化資本が 乏しい家庭の出身者が多いという意味で, 生徒の出自に関しては非常に均質である が，エスニシティの視点から見ると特に都市部の場合極端に多様である。この多様 性にさらに青年文化のスタイルの多様性が加わって, 学校という場でぶつかりあう ことになる。全体としてドイツの学校制度はこれまでその均質性を支配的な特徵と しており, 多様性を取り扱う力に乏しく, 例えば比較的定式化された授業のパター ンやあまり支援的でない指導体制にも現れているように，教育制度における多様化 のアンビバレンスに対する再帰的な対応力が不十分であるといえる。

ドイツの学校制度は, ナチス時代やかつてのドイツ民主共和国（旧東ドイツ）に おいて教育が公的に利用されてきた後, 過去20-30年（各学校の個性化による違い があるとしても）基本的に「授業中心の学校」として発展してきた。青少年の「人 格」を形成することや生活全体にかかわるような幅広い教育を行おうとする動きが 前面に出てくることはなかった。この点は生徒に対してより幅広い教育を行ってい る日本との比較において明確でもある（Toyama-Bialke 2002, Busse/Helsper 
近代化のアンビバレンスの視点から見た教育制度 ·学校・青年期の関係の变容

2004)。このように幅広い教育的関与をドイツが避けてきたことは, 過去の独裁体制 (国家社会主義と旧東ドイツの社会主義)の反省という背景から理解できようが，同 時に学校は青少年と家庭に対して距離をとり, 関与しないという実践を生みだして きた。学校が生徒の人格により責任をもち, 個々の生徒に対し感情的に寄り添い支 援する態度を強め, 生活に関わろうとするコンセプトは, 1960-70年代の旧西ドイ ツの改革時代にすでに取り上げられた主張であったが，現在 2 つ視点から再び論 じられている。一つは, 既に触れたドイツの学校制度における社会的不平等を背景 に, 低階層や移民の子弟など社会的に不利な立場の子どもたちに対し, 学校が補償 教育的な努力を十分していないということである。2 点目は, 家庭構造の変化（シ ングルペアレントや共働き家庭，豊かな社会における貧困層の子どもの問題など） によって，学校が生徒に対し福祉的な役割を担う必要が生まれたことにある。この 2 つは現在, 学校が青少年に昼食や午後の教育サービスを提供するという「終日学 校」の議論において結びついている。余暇活動の機会提供や午後の授業や補習など の形で，学校を生徒を支援する生活世界にしていこうというものである。これによ って生徒が自分の学校に帰属意識を持ち, 意欲低下や柾外感が解消されると考えら れている。他の国（例えば日本も）では，学校が青少年の生活への関与をゆるめる べきではないかと論じているのに対し，ドイツでは教育的関与の拡大について論じ ている。この展開は文明化のアンビバレンスと関連づけられよう。「感情的に認めら れること」が重要になり, 感情的な支えへの欲求は, 青少年の生活環境が不安定化 する中, 学校や専門家が一層必要とされているということにつながっている。しか し単に「感情的に認められること」ゆえにではなく, 特に社会的に周縁化され情緒 的に不安定な生活状況におかれている青少年が, 教育において成功するために必要 な個人化された自己統制を行えない状況にあり, 情緒的に教育上の配慮や支援を必 要としているからといえる。

旧東ドイツの学校制度の変容は, ワルシャワ条約機構の解体後の多くの東欧諸国 の教育制度と同様，近代化のアンビバレンスへの移行として理解できる。旧東ドイ ツの単線型で均質化された学校制度は多様化してきており, 家長主義的で権威主義 的なパターンが支配的であった学校制度は個人化され, 遠隔的な強制によって規定 されるようになっている。また直接的で強い教育態度によって特徴づけられるよう な生徒の全人格に関与していた教育は, 距離を置いた限定的な教育へと変化してい る (Helsper u. a. 2001)。この変容過程の結果と制度レベルでの再編成が教師, 生 徒, 学校にどのような意味を持ったかについてはその後詳細に研究されている。 


\section{2. 子ども・青年にとっての学校の意味}

教育制度における上述の変化は, 子ども・青年の社会化と教育の過程にとって重 要であることはいうまでもない。しかし学校やフォーマルな教育機関はあくまでも 彼らの一つの行動領域にすぎない。近代化の過程とそのアンチノミーは, 教育制度 と生徒の学校への関わりのみならず, 彼らの成長全体の条件に関わるものである (Krüger/Grunert 2002, Helsper/Böhme 2004)。子ども・青年の成長の条件は，さ まざまな領域とその相互関係によって規定される。それは次のような青年期構造の 重要な変容を生み出している。

・ 1 つは, 一階層や生活状況による差を超えて一一, 青年期が長期化しているこ とである。子どもは早く青年期に突入するようになり，青年文化や友人関係にお いて決定に参加したり自己決定する時期が早まり，世代関係も変容している。同 時に成人期への参入は長い教育期間によって遅れている。

・これに加えて，かつての青年期は成人期への短い移行段階に過ぎなかったが，現 在は青年期に特有の発達課題というものがあり, 独自の段階となった。自分なり の構想・スタイルを試したり様々な経験に開放的になることが，高度に近代化さ れた青年期の特徴である。それは既に述べたように，自己統制によって目標を見 据え，自分の教育キャリアを操作し組織化しなければならないという課題と緊張 関係にある。

・独自の段階としての青年期の延長と多様化は, 青年のメディア文化や青年文化の 体験世界と表現の可能性の拡大，青年のメディア文化のグローバル化，地域の青 年サブカルチャーや対抗文化の多様化と関連している。これによって青年特有の 独自の解釈の世界が生まれ，青年期はエクスタシーや表現に満ちた感覚的体験や イベント，スリルへの欲求に満ちたものになる。青年文化的な知の形態や実践が 生まれたり, 他の様々な青年文化のスタイルやサブカルチャーのシンボルの世界 に対抗し，境界線を引いたり，あるいは自らのそれに準拠させようとする事態が 生じる。

・青年期の延長と青年文化の拡大・多様化は, フォーマルな学習・教育過程のほか に，インフォーマルで青年文化的な教育機会に青年が参加する機会を増やしてい る。そこで習得した知識・文化的能力・実践は, 学校のフォーマルな教育提供を 相対化し，ある意味で競争的な関係にある。こうして青年は，彼らにとって刺激 的でクリエイティブな能力を, インフォーマルで青年文化的な教育空間で獲得で 
近代化のアンビバレンスの視点から見た教育制度 ·学校・青年期の関係の变容

きるようになっている。新しいヴァーチャルメディアの知識の世界と情報の拡大 とともに，制度におけるフォーマルな知識へのアクセスというものも相対化され， 学校の知識・伝達の独占は内容的な意味においても相対化されることになる。こ れによって大人, 親, 教師, その他の大人文化の代表者と, 自立を強める傾向に ある青年との関係も相対化され，新しく調整されることになる。

ここで強調すべきは, この構造変容は実際には社会的地位, 生活環境, 地域, 性 別，エスニシティの相互作用する具体的な生活文脈によって異なった形で現れると いうことである。高度に近代化された社会のすべての青年がこの変容の影響下にあ るのだが，それはそれぞれの文脈において独自の形で現れる。それにより青年の生 活状況や生活形態の多様化が生じる。以下ではこの近代化された青年期の全体的文 脈の中からいくつかの側面に焦点を当てる。

社会変容の過程は, 常に教育制度とそこにかかわる人々にとって重要である。第 1 節では, 教育制度自体が変容の影響をどの程度受けているか, 学校関係者の主要 な行動領域がどの程度変容しているかを取り上げた。以下では, 青少年にとって重 要な変容過程であり, 自律性の発達にとって決定的な段階である青年期を取り上げ る。現在のドイツの青年の成長の条件をさまざまな社会化領域の相互作用において 捉えるために，以下では学校に焦点を当て，他の領域と関連づけることにする。そ の際まず学校における適応と成功にとって様々な生活状況や環境はどのような意味 をもっているかを問い, 第 2 に青年と家庭・学校・仲間集団との関係を取り上げる。 第 3 に青年の個人的条件について教育における成功の問題との関連において触れる。

\section{1. 様々な生活状況と生活環境の意味}

PISA が教育制度の変容にとって重要であることについては既に触れたが， 2000 年と 2004 年の比較調査は生徒の社会的背景が学力に影響していることを明らかにし た。かくして社会的な格差は教育拡大によっても解消しなかったことになる。社会 的な格差は少なくとも中等修了証取得に関しては縮小したが，ギムナジウムの修了 証は労働者家庭の青年にとって現在も高いハードルである。社会的不平等は，まず 青年の生活環境や生活状況によって規定されている。親の学歴が低いほど子どもは 高い学歷を達成していない。さらに不平等は教育制度の透過性 (Durchlässigkeit) の低さによっても規定されている。例えば一度基幹学校に入学してしまうと上級学 校に編入するチャンスは乏しくなる。また労働者家庭の子弟は上層の子どもよりも 高い学力を示さなければ, よりレベルの高い学校への推薦を基礎学校から得ること 
ができず，彼らはまた教育制度において最も脱落しやすい集団である。労働者階層 に属することは, 教育制度における適応や学力に関する問題を抱えることとイコー ルであり,このことは教育機会に関して家庭とその社会的地位が重要であることを 示唆している。より極端な結果は移民の青少年において明確で, 彼らは基幹学校と 特殊学校に集中しており, 非移民の生徒よりはるかに落第率が高い。大学入学資格 を得る移民の青年の割合は 80 年代から上昇しているが, 統計的に見てその確率は非 常に低く, 社会的不平等のメカニズムが働いているといえる。親の学歴の低さの他 に, 制度的な差別のメカニズム，すなわち同じアチーブメントが不平等に取り扱わ れることや「言語のハンディ」が, 教育制度における不適応, 成績不振, 挫折等の 主要な要因となっている。ジェンダーをめぐる平等については, 現在女子は男子よ り学力レベルが高い学校種に進学しており, 基幹学校生徒や中途退学者は男子に多 い。青年女子の教育達成は1960年代から非常に高まっているといえるが, 女子は男 子に追いついても, 卒業後不利な立場におかれている (Helsper/Hummrich 2005)。

以上のように不利な立場に置かれている 3 つの集団とは, 低学歷でドイツ語力の 低い家庭出身の移民の青少年, 労働者階層で教育アスピレーションが低い家庭出身 の男子, 様々な問題を抱える家庭出身（すなわち心理社会的な問題があり, 貧困の リスクの高い家庭）の青少年といえる。60年代からの教育改革は不平等の解消に貢 献できなかったが，むしろ教育達成のレベルを上昇させた。70年代の移民募集と移 民の家族の呼び寄せは新しい低階層の形成につながったが，それは教育制度におい ても現れている。教育による不平等の再生産は, 社会の権力と権威関係の再生産と 解釈しなければならない。社会的に問題の多い状況に置かれた青年の場合, この再 生産志向の教育制度によって, 個人レベルの変容が困難になっているのである。

\section{2. 学校・家庭・仲間集団における関係}

教育の不平等の展開については制度的条件のみならず，青少年の行動領域とそこ に生じる関係が教育制度内での成功と挫折にとって重要であることに目を向けなく てはならない。1990年まで東西ドイツにはそれぞれ $2 つ の$ 異なる教育制度があり， 異なる教育理念があった。それは教師生徒関係にも影響を与えたが, 制度的条件が 教師生徒関係に直接影響を与えたわけではない。統一後の変容過程に焦点を当てた 学校文化に関する研究が明らかにしているように, 各学校は個々の学校文化におい て教育理念や神話を形成し, 象徵的な秩序を主張する (Helsper u. a. 2001)。それ 
近代化のアンビバレンスの視点から見た教育制度・学校・青年期の関係の变容

によると学校は，業績のみを基準にして生徒の学校における適応・不適応，成功・ 挫折へと振り分けるようなフォーマル化され官僚主義的で標準化された文脈である ばかりではない。教師生徒関係は限定的役割という特徵のみならず，教師の態度と 学校文化の特徴によっては, 親密さを生み出す曖昧さももっているのである。学校 は教師生徒関係を作り出す空間として捉えられ，認め・認められることや，決定へ の参加，自己責任がそこに特有な形で促進されたり，抑制されたりする。個々の青 年と各学校の学校文化はそれぞれ固有の適合関係にあり, 青年は自身のライフスト ーリー上の経験を基盤にしてそれぞれ特有の形で学校と関わっている（Kramer 2002)。このライフストーリー上の経験は特に60年代から現代化・インフォーマル化 してきた家族関係の影響を受けている。親子関係と世代関係に焦点をあてた研究に よると，家族関係パターンは，伝統的な命令型の上下関係から交涉型の現代化した 関係まで様々である。またその関係は子どもが学校にどうコミットするかにとって 重要であり, 親の教育アスピレーション, 親の社会的地位, 教育に対して親和的か 否かも同様である(Busse/Helsper 2004)。このことは文化資本が特に重要であるこ とを示唆している。例えば日常において重要な文化財の所有（例えば本など）や親 子が共にする文化的実践（会話，観劇やコンサートに行くことなど）は，進学に有 利な影響を及ぼす。宿題に関して厳しい管理主義的な態度をとることはむしろ成績 不振と関連しており, 共通の文化的実践を共有するような刺激を与える態度が高学 力と関連している。経済資本は, ギムナジウムでは家庭教師の授業料から学校外で の学習機会に参加する費用（例えば語学留学など）にいたるまで重要になっている。 仲間集団は青年が学校内外でかかわる第 3 のコンテクストである。年齢が上がる ほど仲間集団に統合されることから，それは基本的に青少年を支援し，社会化にお いて重要なものとみなされている。学校においては向学校的あるいは反学校的な青 年がいるが，仲間集団は大体学力が同じであることが多い。同時に学校種によって 異なるピアカルチャーがあり, 基幹学校では反学校的, 実科学校では順応的, ギム ナジウムでは業績関連の要求には適応するが, 学校に距離を置き, 総合制学校では 業績を重視し，学校を肯定的に評価する文化がある。成績不振者の場合，仲間集団 の文化が反学校的であるため, その志向は問題を引き起こしがちである(「がり勉」 とみなされる危機感から)。高学力は家庭志向や学校への順応との関連する傾向にあ るが，逆に順応を拒否し男性的な行動パターンを志向すると，学校外の青年サブカ ルチャーにコミットしがちである。反学校的な態度は, 暴力的な行動傾向にある青 年にも見られ，暴力志向の青年集団の場合男子ょり女子が極右集団に取り込まれて 
いる。このほかに地域のクラブや学校外の教育機関, 教会系のクラブなどに参加す るか否かは生活環境によって異なる。つまり教育的で上昇志向の生活環境で余暇を 過ごすことは，文化資本の獲得を促進することになる。

家庭・学校・仲間集団の相互関係は，教育における成功にとって非常に重要であ る。特定の仲間集団への接触がそれぞれ特定の進路へと水路づけているのである。 場合によっては仲間集団との関係が学校への適応をサポートするような場合もない わけではないが，基本的には，学校外の教育・余暇サービスの利用等を経由して， 不平等はむしろ再生産されている。家庭・学校関係については，両者の適合関係に よって, 教育における成功が促進されたり抑制されたりするということが分かって いる。学校教育に親和的な親の態度は一般にポジティブに評価されることが多いが, ここにはリスクもある。学校に過剰に順応的な家庭の場合, 親子関係は学校的な要 素によってのみ支配されてしまい，その子ども本人を中心にすえた支援的な態度が 欠落してしまうことがある。家庭・学校が相同的な構造の場合, 個人としての当人 の成長や自律性の獲得が困難になることもある。

\section{3. 学校における適応と成功にかかわる個人的条件}

学習が成立する条件は，一つには一般に「生徒の好奇心」と呼ぶべき要因であり， それは自律性や能力獲得への欲求など子ども・青年の意欲に関わる側面である。も う一つは関心や能力などの個人的要因である。学校の評価過程に青年がどう対応す るかはそれぞれ異なっているが, 教育心理学の研究によると, 青少年の能力に関す る自己評価は学校への適応が進むほど成績に左右されている (Helmke 1998)。成績 に関するプレッシャーや教師の厳しい統制が強く, 生徒間の競争が激しい環境では, 生徒（特に成績不振者）のアチーブメント関連の不安は高まるという。だが成績上 位者は不安をもたず，下位者が学校への不安感を持つと考えるのは早計で, トップ の成績の生徒はその地位を失うまいとする不安が強く, 逆に成績不振者の場合, 学 校卒業（ 9 年生まで）が間近に迫り, 学校外の友人関係によりコミットするため, 自己像にとって学校の成績の意味が縮小して不安感が減少するという。年齢が上昇 すると学校の成績によって自己像が左右されることはなくなってゆく。

社会の近代化の過程は学校の意味をアンビバレントなものにしている。ひとつに は学歴がより重要になっており, 他方で就職の保証ではなくなってきているという ことがある。学校で挫折することで社会的に孤立するという脅威と, 青年が自分の 世界や仲間関係へのコミットを強めていくこととは相補的な関係にある。というの 
近代化のアンビバレンスの視点がら見た教育制度・学校・青年期の関係の变容

も年齢とともに後者によりコミットすることで, 青年は学校の主観的重要性を低下 させることができるからである。しかしこの両者に対照的にコミットすることが, 学校関係のアンビバレンスを克服する唯一の方法とは限らない。これまでの研究に おいて確認されているのは, 学校以外の問題を抱えるゆえに, 生活において経験す る緊張を，学校にできる限り適応することで解消しょうとする場合もあるというこ とである。例えば Nittel(1993)によると，学校のフォーマルな資格付与の側面にの み手段的・戦略的な意味を見出し, 学校における特定の側面に焦点化してコミット する生徒がいるという。そのような生徒の態度は, エスニシティによって差別され ているケースや, 家庭の伝統から逃れるために学校がその生徒にとって自由な空間 となっているようなケースに特に見られることがわかっている。

\section{3. 近代化のアンビバレンスの中での成長—今後の研究展開への課題}

社会・教育制度・青年期の変容を全体的に展望することは, その変容が相互に複 雑に関連しあい，多面的であるゆえに容易ではない。「普遍的テーゼ」が可能である とすれば，近代化のアンビバレンスが拡大する中での成長についてのテーゼをまと めることであろう。そこで最後にこれまでの概観の中からこれに関するいくつかの 重要な知見のみをまとめることにする。近代化のアンチノミーは, 高度に近代化さ れた社会に共通する社会的・文化的変容の次元の緊張関係である。それぞれの国や 文化の文脈によって近代化のアンビバレンスは独自の形態をとり, 一一本稿ではド イツの学校制度を例に示したが—その独自な形で制度的発展に浸透する。その際, 制度的変容に関して, 制度自身もまた近代化のアンビバレンスの独自な形態化に貢 献しているのである。本稿では生徒に対して教育制度が突きつけている要求や，そ こでの彼らの経験が矛盾をはらんだものであることを示してきた。例えば様々な教 育の可能性の拡大によって教育キャリアの個人化が強まる一方, その失敗のリスク に関しては自己責任が拡大し, 教育における成功に新たな形で依存する状態が生ま れている。また子ども・青年が緊張に満ちた変化に直面している生活領域は一つだ けではない。学校以外の領域でもそのようなアンビバレンスがあり, 多様な領域同 士も緊張関係におかれている。それが特に顕著なのは, 例えば業績中心の学校と, 表現・体験志向の青年文化の関係であろう。青少年は，この様々な要求の緊張関係 の中で難しいバランスを取らなければならず，この挑戦に応じなければならない。 こうした要求や挑戦に個々の青年がどう対応するかは, 実際にはそれぞれの地域や ローカルな文脈によって異なるため, そこに生活環境, 集団, あるいは青少年個人 
に特有の生活スタイルが生まれるのである。また彼らの生活スタイルは, 生活環境, ジェンダー, エスニシティのローカルな布置関係によって異なる要求を, 青年がど う解釈し, どう対応したかという表れなのであり, 青年のライフストーリー (自伝) の多様化として表れている。またこのアンビバレンスに個人がどうかかわろうとし， それが当人の自己にどのような意味をもっているかは, 個々の青年の人生の物語の 中に見ることができる。

このような近代化のアンチノミーにおける成長のテーゼを前提とするならば，社 会科学および教育研究の今後の課題はどのようなものになるだろうか。以下ではい くつか近年の動向と今後の課題をいくつか挙げる。

・国および文化間の違いについて, 各国独自の展開を比較する研究が必要である。 例えば，選抜と教育の不平等の問題は国際的にみても解消されていないが，国に よって重要な違いも存在している（Baumert u. a. 2001, Prenzel u. a. 2004）。

・多様なレベルを相互に関連づける研究も必要である。全体的な社会変容が社会化 機関や生活世界, 生活環境, 相互作用のネットワークにどのような影響をもたら すかといった研究である。ドイツ統一後の制度の変容がもたらした帰結に関する 研究はこのような研究群に含まれる (Helsper u. a. 2001)。

- 青少年の行動領域間の相互関係（例えば家庭と学校, 家庭と仲間集団, 学校と仲 間集団など）に焦点をあてる研究も重要である。そのような研究は多様な生活領 域間の複雑な相互作用やそこに生まれる青年への要求に焦点を当てている (Busse/Helsper 2004)。

・マクロとミクロを関連づけ，数量的および質的アプローチを組み合せることで, マクロレベルの構造的変容とそれが青年の成長に及ぼす具体的で多様な影響との 間の様々な関係を捉えることができる。

・最後に子ども・青年の発達過程に焦点を当て, とりわけ制度ないし生活環境の研 究と関連づける研究が必要である。これについては近年, 青少年の教育過程に関 する縦断的研究がうまれている（Fend 2000）。また学校や教育過程の意味を個人 の人生の軌跡の全体的文脈において捉えた生徒のライフストーリー研究もその一 つである。

以上のようなアプローチによって，成長のアンビバレンスのその複雑さを捉える ことができる。すなわちマクロレベルのグローバルな近代化の過程と, そのアンビ バレンスに青年や青年文化がどう関わるか, またそこに生まれる多様な形態の自伝 的過程との間の緊張関係へのアプローチが可能になろう。 